\title{
TJES
}

ISSN: 1813-162X

Tikrit Journal of Engineering Sciences

available online at: http://www.ti-es.com

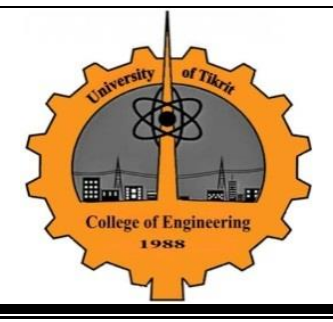

\section{Rainfall Data Analysis and Study of Meteorological Draught in Iraq for the Period 1970-2010}

\author{
Taymoor A. Awchi ${ }^{1 *}$ \\ Ansam I. Jasim ${ }^{2}$ \\ ${ }^{1}$ Dams \& Water Resources Engineering Department, University of Mosul, Mosul, Iraq \\ Email: awchi2002@yahoo.co.in \\ ${ }^{2}$ Dams \& Water Resources Engineering Department, University of Mosul, Mosul, Iraq
}

(Received 13 December 2016, Accepted 22 March 2017, Available online 31 March 2017)

\begin{abstract}
This work aimed to analyze and evaluate the metrological draught in Iraq. Monthly rainfall data were collected from 22 meteorological stations scattered all over Iraq for the period 19702010. Various statistical tests have been performed to examine the data accuracy, e.g. Consistency test, Trend analysis, as well as homogeneity test. The Standard Precipitation Index (SPI) and Theory of Runs are used to analyze the metrological draught and evaluating the draught characteristics. SPI values have been estimated for 12-month time scale, from January to December. To analyze the drought characteristics, the accumulative deficit, drought duration and intensity for each station have been estimated. The results showed that the rainfall data series considered in the study are all consistent with negative trends except Hilla station, random except Haditha and Samawah stations and homogeneous. It was shown that the study area has been suffered from sequent drought events through nearly half of the years considered in the study, and the worst were in 1997-2001 and 2007-2010 in which extreme droughts were dominated several parts of study area.
\end{abstract}

Keywords: Meteorological drought, Iraq, theory of runs, standard precipitation index.

\footnotetext{
تحليل بيانات الامطار ودراسة الجفاف المناخي في العراق للفترة 1970-2010

تهدف هذه الدراسة الى تحليل وتقييم الجفاف المناخي في العراق. تم جمع بيانات الامطار الثهرية من 22 محطة انواء التهاء

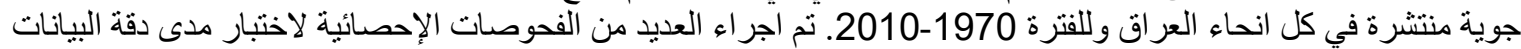
وموثوقيتها، منها فحص الاتساق وفحص الاتجاه العام فضلا عن فحص التجانس. استخدم في هذا البحث دليل الجيل المطر القياسي

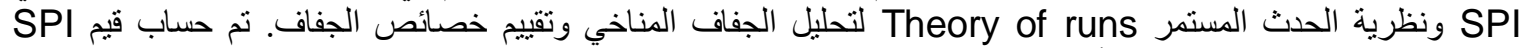

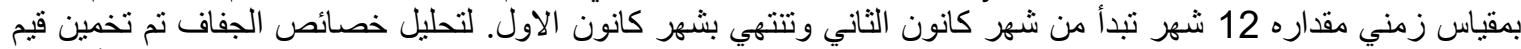

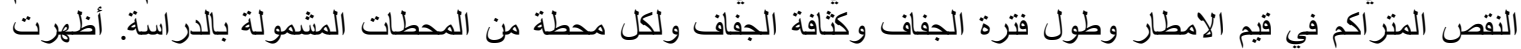

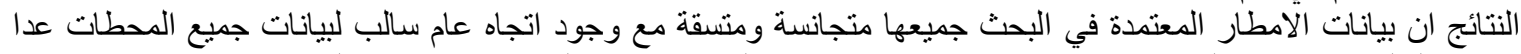

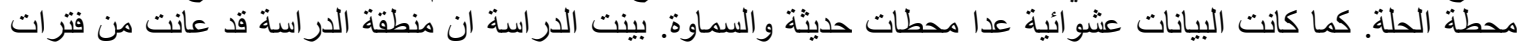

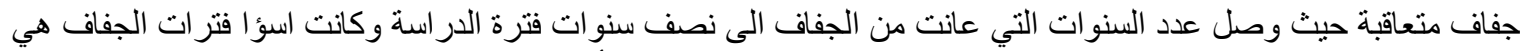

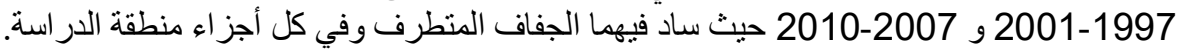

الكلمات الدالة: الجفاف المناخي، العراق، نظرية الحدث المستمر، دليل المطر القياسي.
}

*Corresponding author: E-mail : awchi2002@yahoo.co.in 


\section{Introduction}

Drought is a temporary feature resulting from prolonged absence, or deficiency or poor distribution, of precipitation (Ogallo, 1994)[1]. It is a natural recurrent phenomenon, which occurs in different temporal and spatial scales. Drought is difficult to define due to its strong dependency on time and space, and its variety of effects.

A drought is an indistinct event of water deficiency that results from the combination of many integrated factors, and neither the start nor the termination can be exactly defined (Kossida et al. 2009)[2]. Although numerous interpretations of drought have been offered, the most significant determinant of drought is the amount of precipitation an area gets compared to normal (Edwards and Mckee, 1997)[3]. Types of drought can be defined by the effect on specific scopes and are classified into meteorological, agricultural, hydrological and socio-economic droughts. Meteorological drought is associated with a precipitation deficit and it depends upon its duration, which can cause agricultural (related to soil moisture) or hydrological drought (related to e.g. stream flow, groundwater level, or reservoir storage). Socio-economic drought addresses the monetary effects of drought (Norouzi et al., 2012)[4].

Drought planners usually rely on some mathematical indices to decide when to carry out water conservation or mitigation measures against drought (Loucks and Bee 2005)[5]. Drought indices are tools for measuring and analysing drought severity. These indices reflect the impact of drought on different types of water sources. Such indices differ by drought type and variables included in these indices (Wilhite and Glantz 1985, Svoboda and Coauthors 2002)[6,7]. Widely used indices in drought studies include the Palmer Drought Severity Index, PDSI (Palmer, 1965)[8], the Standardized Precipitation Index, SPI (McKee et. al. 1993)[9], Effective Drought Index, EDI (Byun and Wilhite, 1996)[10], Reconnaissance Drought Index, RDI (Tsakiris et. al. 2007)[11], Standardized Precipitation Evapotranspiration Index, SPEI (Vicente-Serrano et. al., 2010)[12], Soil Moisture Index, SMI (Nam et. al. 2012) [13], Integrated Surface Drought Index, ISDI (Wu et. al. 2013) [14], Multivariate Standardized Drought Index, MSDI (Hao and AghaKouchak, 2013) [15]. Although that the literature showed verity of drought indices, but the Standard precipitation Index SPI is the most used index (Edossa et al. 2010)[16].

Iraq is one of the countries in the middleeast region, which suffered from frequent drought events in the last decades. This had serious influences on the water resources, irrigated and rainfed agriculture, areas of cultivated lands, desertification and demographic distribution, which consequently caused serious economic problems for the country. The research works regarding droughts in the country are rare, therefore, the current work aims to study and analyse the meteorological drought in Iraq using the SPI. The study included analysing the rainfall data with different methods to ensure its homogeneity, consistency and randomness.

\section{Study Area}

The study considered the entire area of Iraq within its borders. Iraq lies in a semi-arid region between longitudes $38^{\circ} 45^{\prime}$ and $48^{\circ}$ $45^{\prime}$ and latitudes $29^{\circ} 5^{\prime}$ and $37^{\circ} 22^{\prime}$ with an area of $437,049 \mathrm{~km}^{2}$. It has different terrain types including mountainous territory in the north and north-east, desert territories in the west and south-west, and marshlands in the south, resulting in different climate characteristics from a region to another. Monthly rainfall data have been collected from 22 meteorological stations (i.e. Mosul, Duhok, Erbil, Sulaymaniyah, Kirkuk, Khanqin, Tel-Afer, Dukan, Darbendikhan, Baiji, Baghdad, Qaim, Rutba, Hai, Nasiriya, Hilla, Basra, Nukheb, Ramadi, Samawa, Hadithah and Sinjar) for the period 1970-2010. Figure (1) demonstrates the study area and locations of meteorological stations considered in the study, and Figure (2) shows the spatial distribution of the average annual rainfall for the period 1970-2010.

Figure (2) proves that the annual rates of rainfall varies with the terrain. Highest rates of annual rainfall are noticed in the northeastern part of Iraq, including Dukan, Sulymania, and Darbandikhan, which range from 659 to $736 \mathrm{~mm}$. Rates of annual rainfall decline on southwards and westwards 
direction. Lowest average annual rainfall rates have been recorded in Nukheb station in the south-western part of Iraq with only 74 $\mathrm{mm}$.

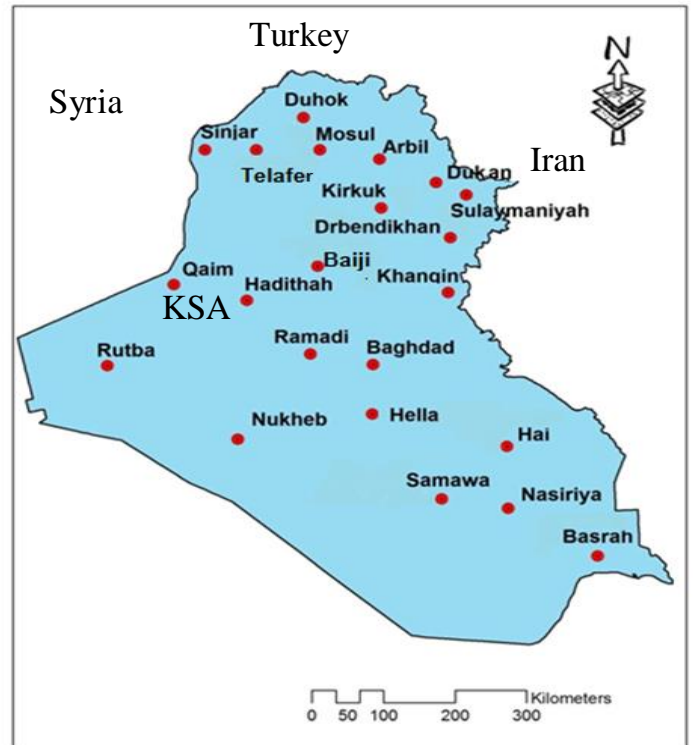

Fig. 1. The study area and locations of the selected meteorological stations

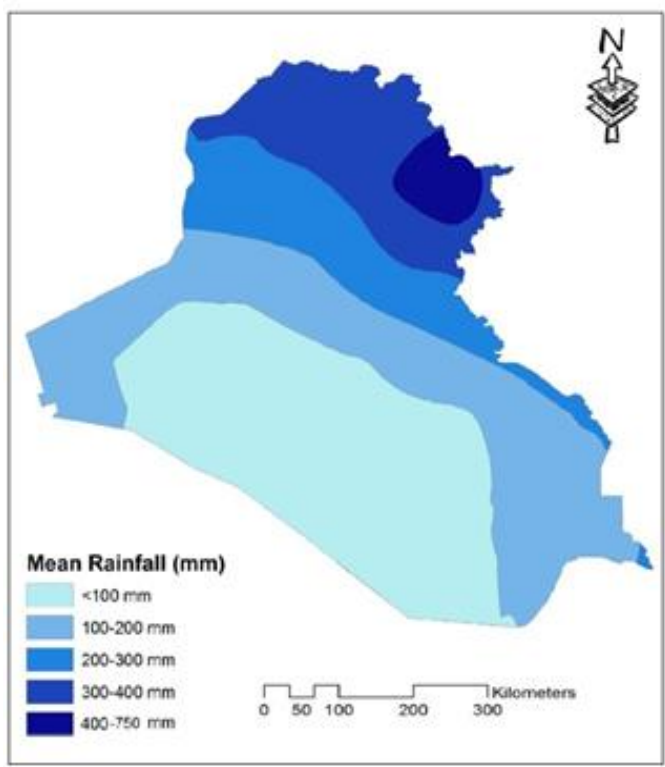

Fig. 2. The spatial distribution of annual rainfall for the period $1970-2010$

\section{Data Preparation}

Precipitation is considered as the main natural source of fresh water resources, especially for arid and semi-arid environments. However, the rainfall at these environments characterized with low scale depth, non-uniform distribution with inequality quantities from year to year. Statistical tests, annual precipitation accumulates and their spatial and temporal distribution estimation are essential procedures for the data collected from meteorological stations prior to any draught study. Table (1) shows the salient statistical features of rainfall data of the selected stations.

\section{Estimation of Missing Rainfall Data}

Rainfall records in all meteorological stations covered by the study experience different periods of missing data which may reach in some stations as long as twelve years, continuous or intermittent, and differ from one station to another. Thus, missing data values have been estimated by adopting two methods, i.e., Arithmetic Average Method and Normal Ratio Method. These two methods rely on the estimate of specific station precipitation values by considering the precipitation data of neighbouring stations (Varshney et al., 1979)[17].

The records of two stations, i.e., Ramadi and Qaim stations, have a lack of 12 years. It is difficult to estimate these data by the above-mentioned methods, thus, the linear regression method was used to link the data of the aforesaid two stations and the neighbouring stations. The following equation has been suggested to estimate the missing data for Ramadi station using the data of Ramadi, Rutba, Baiji, Haditha, and Baghdad stations with regression coefficient $\left(R^{2}\right)$ of 0.709 .

$R_{\text {Ramadi }}=0.444+0.0823 \quad R_{\text {Haditha }}+0.144$

$R_{\text {Baghdad }}+0.259 R_{\text {Baiji }} 0.29 R_{\text {Rutba }}$

As for Qaim station, the following equation has been suggested with a regression coefficient $\left(R^{2}\right)$ of 0.588 .

RQaim $=3.667+0.725^{\star} R_{\text {Rutba }}$

Where $R_{x}$ is the monthly rainfall data $(\mathrm{mm})$ at station $\mathrm{x}$ 
Table 1. Preliminary statistics of rainfall data for the selected meteorological stations

\begin{tabular}{lccccccc}
\hline Station & $\begin{array}{c}\text { Elevation } \\
(\mathrm{m})\end{array}$ & Longitude & Latitude & $\begin{array}{c}\text { Annual } \\
\text { rainfall } \\
\text { mean } \\
(\mathrm{mm})\end{array}$ & $\begin{array}{c}\text { Standard } \\
\text { deviation } \\
(\mathrm{mm})\end{array}$ & $\begin{array}{c}\text { Minimum } \\
\text { annual } \\
\text { rainfall } \\
(\mathrm{mm})\end{array}$ & $\begin{array}{c}\text { Maximum } \\
\text { annual } \\
\text { rainfall } \\
(\mathrm{mm})\end{array}$ \\
\hline Nukheb & 305 & $42^{\circ} 15^{\prime}$ & $32^{\circ} 02^{\prime}$ & 74 & 38 & 24 & 200 \\
\hline Samawa & 6 & $45^{\circ} 16^{\prime}$ & $31^{\circ} 18^{\prime}$ & 92 & 50 & 15 & 228 \\
\hline Hilla & 25 & $44^{\circ} 26^{\prime}$ & $32^{\circ} 11^{\prime}$ & 94 & 36 & 41 & 192 \\
\hline Rutba & 615.5 & $40^{\circ} 17^{\prime}$ & $33^{\circ} 02^{\prime}$ & 114 & 59 & 23 & 264 \\
\hline Ramadi & 48 & $43^{\circ} 19^{\prime}$ & $33^{\circ} 27^{\prime}$ & 114 & 46 & 56 & 241 \\
\hline Baghdad & 32 & $44^{\circ} 14^{\prime}$ & $33^{\circ} 14^{\prime}$ & 117 & 49 & 50 & 284 \\
\hline Nasiriya & 3 & $46^{\circ} 14^{\prime}$ & $31^{\circ} 05^{\prime}$ & 121 & 53 & 46 & 246 \\
\hline Qaim & 178 & $41^{\circ} 10^{\prime}$ & $34^{\circ} 23^{\prime}$ & 121 & 58 & 23 & 284 \\
\hline Hadithah & 140 & $42^{\circ} 22^{\prime}$ & $34^{\circ} 04^{\prime}$ & 122 & 58 & 39 & 274 \\
\hline Hai & 14.9 & $46^{\circ} 03^{\prime}$ & $32^{\circ} 10^{\prime}$ & 134 & 57 & 55 & 290 \\
\hline Basra & 2.4 & $47^{\circ} 43^{\prime}$ & $30^{\circ} 34^{\prime}$ & 136 & 57 & 32 & 297 \\
\hline Baiji & 115 & $43^{\circ} 29^{\prime}$ & $34^{\circ} 55^{\prime}$ & 198 & 71 & 85 & 377 \\
\hline Khanqin & 202.2 & $45^{\circ} 26^{\prime}$ & $34^{\circ} 18^{\prime}$ & 289 & 88 & 72 & 457 \\
\hline Tel-Afer & 200 & $42^{\circ} 29^{\prime}$ & $36^{\circ} 22^{\prime}$ & 314 & 112 & 134 & 614 \\
\hline Kirkuk & 330.8 & $44^{\circ} 24^{\prime}$ & $35^{\circ} 28^{\prime}$ & 355 & 132 & 135 & 696 \\
\hline Sinjar & 538 & $41^{\circ} 50^{\prime}$ & $36^{\circ} 19^{\prime}$ & 355 & 134 & 164 & 663 \\
\hline Mosul & 223 & $43^{\circ} 09^{\prime}$ & $36^{\circ} 19^{\prime}$ & 358 & 111 & 194 & 633 \\
\hline Erbil & 426 & $44^{\circ} 20^{\prime}$ & $36^{\circ} 11^{\prime}$ & 420 & 128 & 157 & 886 \\
\hline Duhok & 536 & $43^{\circ} 00^{\prime}$ & $36^{\circ} 50^{\prime}$ & 553 & 173 & 277 & 911 \\
\hline Darbandikhan & 400 & $45^{\circ} 45^{\prime}$ & $35^{\circ} 08^{\prime}$ & 659 & 186 & 296 & 1041 \\
\hline Sulaymaniyah & 853 & $45^{\circ} 27^{\prime}$ & $35^{\circ} 33^{\prime}$ & 706 & 178 & 339 & 1085 \\
\hline Dukan & 490 & $44^{\circ} 57^{\prime}$ & $35^{\circ} 57^{\prime}$ & 735 & 221 & 366 & 1468 \\
\hline & & & & & & &
\end{tabular}

\section{Theoretical Background}

\section{Statistical Tests of Rainfall Data}

The statistical analyses of hydrological time series data considered in water resources planning studies are based on a set of major assumptions, e.g. the series is consistent, is trend-free and makes up a stochastic process whose random part follows the appropriate probability distribution function. Consistency indicates that all the collected data belong to the same statistical population. Trend exists in a data set if there is a significant positive or negative correlation between time and the observations. Trend is normally presented through human activities. Randomness in a hydrological time series means that the data arise from natural causes. If there is no randomness, then the series is persistent; this persistence is normally quantified in terms of the serial correlation coefficient (Adeloye and Montaseri 2002)[18]. In this paper, the rainfall data series of the selected stations have been encountered several statistical analysis to prove their consistency, randomness and homogeneity.

\section{Test for Consistency of record}

Double mass curve is used to check the consistency of many kinds of hydrologic data by comparing data for a single station with that of a pattern composed of the data from several other stations in the area. The double-mass curve can be used to adjust inconsistent precipitation data. The graph of the cumulative data of one variable versus the cumulative data of a related variable is a straight line so long as the relation between the variables is a fixed ratio. Breaks in the double-mass curve of such variables are caused by changes in the relation between the variables. These changes may be due to changes in the method of data collection or to physical changes that affect the relation (Adeloye and Montaseri, 2002)[18]. Accumulated rainfall for the specific station as well as the accumulated values for adjacent main stations shall be calculated. Then, the relation is drawn between them as shown in Figure (3).

$\mathrm{Pcx}=\mathrm{Px} * \frac{\mathrm{Mc}}{\mathrm{Mg}}$ 
Where Pcx is the corrected precipitation at time period $t_{1}$ at station $x, P x$ is original recorded precipitation at time period $t_{1}$ at station $\mathrm{x}, \mathrm{Mc}$ refers to the corrected slope of the double mass curve and $\mathrm{Ma}$ is the original slope of the mass curve.

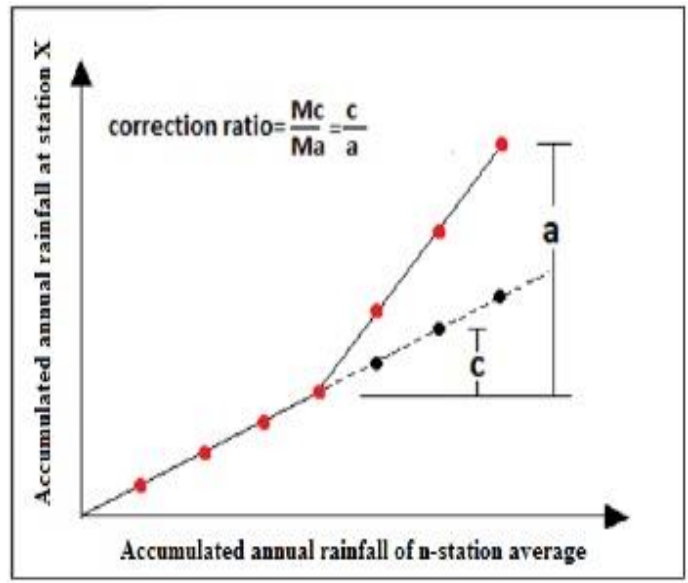

Fig. 3. Annual rainfall data consistency test

\section{Precipitation Trend Analysis}

Trend is defined as the slight change of a phenomenon from time to another with no impact except after a long time. When numbers indicate to increase, the direction is positive, while the opposite is negative. Many statistical techniques (parametric or non-parametric) have been developed to detect trends within time series such as linear regression method, Spearman's Rho test, Mann-Kendall test, Sen's slope estimator, Bayesian procedure (Gocic and Trajkovic, 2013; Karpouzos et al., 2010) $[19,20]$. In this study, the linear regression method was used to analyse the precipitation trend. In this method, the trend of data may be recognised through the following equation (Gocic and Trajkovic, 2013; Ngongondo et al. 2011) [19,21].

$\mathrm{Y}=\mathrm{a}+\mathrm{bx}$

Where $\mathrm{x}$ is the explanatory variable (years), $\mathrm{Y}$ is the dependent variable (rainfall, $\mathrm{mm}$ ), $b$ is the slope of the line ( $\mathrm{mm} /$ year) and $a$ is the intercept.

\section{Homogeneity Test}

Test of homogeneity means the detection of variation in a dataset. If such data are homogenous, this means that data were measured at the same time with the same tools and circumstances (Kang and Yusof, 2012)[22]. Two groups of homogeneity testing techniques can be distinguished and are usually referred to as absolute and relative methods. In the first set of procedures, the statistical tests apply to each station data separately. In the second set, the test uses records from neighboring stations (named reference stations) which presumably are homogeneous. There are several techniques for testing homogeneity in the literature. The widely used techniques are the Standard Normal Homogeneity Test (SNHT), Buishand Test and Pettitt Test (Piticar and Ristoiu, 2012)[23].

The SNHT test was proposed by Alexandersson (1986)[24] to detect the inhomogeneity in the time series. In this test, null hypothesis $\left(\mathrm{H}_{\mathrm{o}}\right)$ assumes that data are random and independent amounts that are identically and normally distributed. The alternative hypothesis $\left(\mathrm{H}_{1}\right)$ it assumes that there is a break in the mean. This test is more sensitive to breaks near the beginning and end of the time series (Ngongondo et al. 2011)[21].

In this test, a statistic $T y$ is used to compare the mean of first part of data ( $y$ of years) with the remaining part ( $n-y$ of years) and can be written as below (Şahin and Ciğizoğlu, 2010, Kang and Yusof, 2012) [25,22].

$$
\begin{aligned}
& \text { Ty }=y \bar{z}_{1}+(n-y) \bar{z}_{2}, y=1,2, \ldots n \ldots \ldots(5) \\
& \bar{z}_{1}=\frac{1}{y} \sum_{i=1}^{n} \frac{\left(y_{i}-\bar{y}\right)}{S} \ldots \ldots \ldots \ldots \ldots \ldots \ldots \ldots(6) \\
& \bar{z}_{2}=\frac{1}{(n-y)} \sum_{i=y+1}^{n} \frac{\left(y_{i}-\bar{y}\right)}{S} \ldots \ldots \ldots \ldots \ldots \ldots(7)
\end{aligned}
$$

The year $y$ is having a break if value of $\mathrm{T}$ is maximum. To reject null hypothesis, the value of $T_{0}$ is compared with critical values shown in the Table 2 which depend on data size (Kang and Yusof, 2012)[22].

$\mathrm{T}_{\mathrm{o}}=\max \mathrm{T}_{\mathrm{y}}$

Where $\mathrm{n}$ is the number of total years, $\mathrm{S}$ is standard deviation, $\bar{y}$ is mean of total data and $\bar{z}_{1}, \bar{z}_{2}$ are the first and second data part averages.

The Buishand test was first proposed by Buishand (1982)[26] in which the null hypothesis $\left(\mathrm{H}_{\mathrm{o}}\right)$ assumes that data are random, independent and normally distributed. The alternative hypothesis $\left(\mathrm{H}_{1}\right)$ assumes that there is a break in the mean. 
This test is more sensitive to breaks in the middle of time series (Costa and Soares, 2009)[27]. The homogeneity test can be based on the cumulative deviations from the mean or adjusted partial sums, which are defined as follows (Şahin and Ciğizoğlu, 2010)[25]:

$\mathrm{S}_{\mathrm{y}}=\sum_{\mathrm{i}=1}^{\mathrm{y}}\left(\mathrm{Y}_{\mathrm{i}}-\overline{\mathrm{Y}}\right), \quad \mathrm{y}=1,2, \ldots, \mathrm{n}$

When data series is homogenous, the $S_{y}$ values will rise and fall around zero. The year y has a break when $S_{y}$ has reached a maximum (negative shift) or minimum (positive shift). Adjusted range $\mathrm{R}$ is obtained by

$\mathrm{R}=\frac{\max _{\mathrm{y}}-\operatorname{mins}_{\mathrm{y}}}{\mathrm{S}}$

The value $(R / \sqrt{n})$ is then compared with the critical values given by Buishand (1982)[26], (See Table (2)).

The approach after Pettitt (1979)[28] is commonly applied to detect a single changepoint in hydrological series or climate series with continuous data. . This test is more sensitive to breaks near the middle of the time series (Costa and Soares, 2009)[27]. It is based on the rank, $r i$ of the $y_{i}$ and ignores the normality of the series (Şahin and Çiğizoğlu, 2010; Kang and Yusof, 2012)[25,22].

$x_{y}=2 \sum_{i=1}^{y} r_{i}-y(n+1), y_{i}=1,2, \ldots, n \ldots \ldots$

The break occurs in year $k$ when

$$
\mathrm{X}_{k}=\max \left|\mathrm{X}_{\mathrm{y}}\right|
$$

The value $\mathrm{X}_{k}$ is compared with the critical value given by Pettitt (1979)[28] and shown in Table (2).
In this study, a significance level of $5 \%$ was adopted for the above-mentioned tests. If the value of the test exceeds the critical value at the specified confidence level, the null hypothesis $\left(\mathrm{H}_{\mathrm{o}}\right)$ will be rejected, or, if the estimated value is greater than the critical value, the null hypothesis $\left(\mathrm{H}_{0}\right)$ will be rejected. While the alternative hypothesis $\left(\mathrm{H}_{1}\right)$ will be accepted at the same confidence level.

\section{Randomness Test}

Randomness in hydrological data series means that data arise out of natural reasons (McMahon and Mein, 1986)[29]. Randomness testing is summarised in calculating the data series median. Each data item is examined whether it exceeds the median. If a data item exceeds the median, then this is considered a success case (replaced by letter $n_{1}$ ); otherwise, it is a failure case (denoted by letter $n_{2}$ ). Cases that are exactly equal to the median are excluded and the number of each of $n_{1}$ and $n_{2}$ shall be counted. The value of $r$, which is $\left(n_{1}+n_{2}\right)$, shall be calculated, consequently the following equation is used to calculate the values of the standard normal variable $Z$ (Adeloye and Montaseri, 2002)[18].

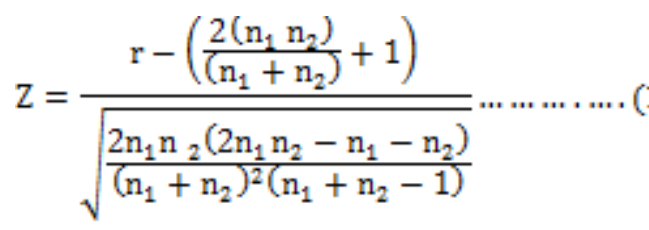

The calculated value of $Z$ shall be compared with the normal distribution table at a confidence level of $5 \%$ with the null hypothesis $\left(H_{0}\right)$ being rejected if $Z>Z_{\alpha / 2}$.

Table 2. Critical values of homogeneity tests (Vezzoli et al., 2012) [30]

\begin{tabular}{lccccccc}
\hline \multirow{2}{*}{ Test } & Sig. & \multicolumn{7}{c}{ Data size $(\mathrm{n})$} \\
\cline { 3 - 8 } & level & 20 & 30 & 40 & 50 & 70 & 100 \\
\hline \multirow{2}{*}{ SNHT } & $1 \%$ & 9.56 & 10.45 & 11.01 & 11.38 & 11.89 & 12.32 \\
& $5 \%$ & 6.95 & 7.65 & 8.1 & 8.45 & 8.8 & 9.15 \\
\hline \multirow{2}{*}{ Buishand } & $1 \%$ & 1.6 & 1.7 & 1.74 & 1.78 & 1.81 & 1.86 \\
& $5 \%$ & 1.43 & 1.5 & 1.53 & 1.55 & 1.59 & 1.62 \\
\hline \multirow{2}{*}{ Pettitt } & $1 \%$ & 71 & 133 & 208 & 239 & 488 & 841 \\
& $5 \%$ & 57 & 107 & 167 & 235 & 393 & 677 \\
\hline
\end{tabular}




\section{Drought Analysis}

\section{Standardized Precipitation Index (SPI)}

McKee et al. (1993)[9] developed the Standard Precipitation Index (SPI) for the purpose of defining and monitoring drought. One of the main advantages of the SPI is that it only requires rainfall data as an input, which makes it perfect for areas where data collection is not as extensive and makes its evaluation relatively easy. SPI is a standardized index, which ensures independence from geographical position as the index in question is calculated regarding the average precipitation in the same place (Cacciamani et al. 2007)[31]. SPI was developed to quantify the precipitation deficit for multiple time scales, reflecting the impact of rainfall deficiency on the availability of various water resources. They calculated the SPI for 3, 6, 12, 24, and 48-month scales to reveal the temporal performance of the impact. The SPI provides a quick and handy approach to drought analysis (Umran Komuscu, 1999)[32].

The computation of the SPI drought index is based on the long-term rainfall record (at least 30 years). The rainfall time series is fitted to a gamma distribution, which is then transformed through an equal probability transformation into a normal distribution. Positive SPI values indicate wet conditions with higher than median precipitation, and negative SPI values indicate dry conditions with lower than median precipitation (Bordi and Sutera, 2007)[33]. The procedure of calculating SPI has been detailed in McKee et al. (1993)[9] and Table 3 shows SPI drought classes.

Table 3. Drought classification based on the SPI value (McKee et al. 1993)[9]

\begin{tabular}{ll}
\hline SPI value & Drought Class \\
\hline$\geq 2$ & Extremely wet \\
1.5 to 1.99 & Severely wet \\
1.0 to 1.49 & Moderately wet \\
0 to .99 & Mid wet \\
-.99 to 0 & Mild dry \\
-1.49 to -1.0 & Moderately dry \\
-1.99 to -1.5 & Severely dry \\
$-2.0 \geq$ & Extremely dry \\
\hline
\end{tabular}

\section{Theory of Runs}

Yevjevich (1967)[34] proposed the theory of runs as a tool for identifying drought and studying its characteristics. Theory of runs is defined as a series of similar events which are preceded and followed by different events. Theory of Runs can be used to describe the metrological drought. Drought threshold may be a fixed value in case of annual values (no seasonal variations), or may be seasonal variable values when seasonal data are used. The truncation level should be selected in each period depending on the purpose of the study. This value is often considered to be equal to the long-term mean or median for the time series to be studied. Other choices also considered such as adopting a percent of the mean or through a specific probability. The advantage of using the theory of runs in identifying drought characteristics is the ability of deriving the probabilistic aspects of drought characteristics, such as drought period length, drought accumulated deficit in an analytical concept or through using generated data when stochastic characteristics of study's basic variable are known. New methods were derived to evaluate return periods for drought events, which depend on theory of runs. Thus, this theory is ideal for studying and analysing drought risks (Cancelliere et al., 2005).

Main drought variables, which can be estimated by theory of runs and shown in Figure (4) are the drought duration, accumulated deficit and intensity (Sirdaş and Şen, 2003). Drought duration $L$ is the number of successive periods experiencing rainfall deficit. The accumulated deficit $M$ is the sum of rainfall deficits compared to their averages, which can be estimated by the following equation:

$$
\mathrm{M}_{\mathrm{j}}=\sum_{\mathrm{i}=1}^{\mathrm{m}} \overline{\mathrm{X}}-\mathrm{X}_{\mathrm{i}} \ldots \ldots \ldots \ldots(
$$

Where $M_{j}$ is the accumulated deficit for drought $\mathrm{j}, \mathrm{m}$ is number of deficits during drought $j, X_{i}$ is rainfall at time $I$ and $\bar{X}$ is the average of rainfall time series. Drought intensity $I$ is the ratio between the accumulated deficits to drought duration. 


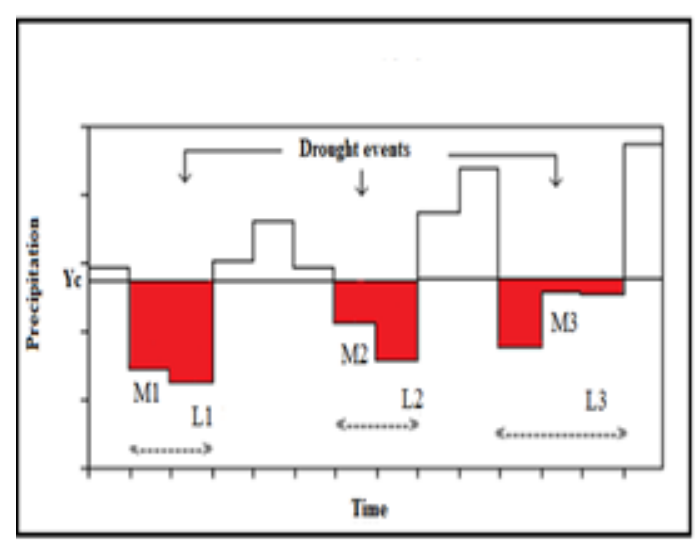

Fig. 4. Drought identification with the theory of runs

\section{Results and Discussion Statistical Tests of Rainfall ata}

The consistency test results showed that monthly rainfall data for the selected stations within the study period experienced no breaks in rainfall data, which shows that the data of the selected stations are of consistent nature.

Regarding trend of rainfall, the trends of rainfall data series of each station were drawn to recognize if it exists. Results revealed that negative trends exist in rainfall data series of all stations covered by the study except for Hillah station as shown in the Table (4).

Table 4. Annual rainfall trend equations for the selected stations

\begin{tabular}{llll}
\hline Station & Trend equation & Station & Trend equation \\
\hline Khanqin & $y^{*}=361.061-3.1625 x^{\prime}$ & Hai & $y=171.688-1.73453 x$ \\
Qaim & $y=134.53-0.617211 x$ & Basra & $y=157.64-1.06071 x$ \\
Mosul & $y=405.13-2.2086 x$ & Nasiriya & $y=130.588-0.450202 x$ \\
Duhok & $y=49.7657-1.502 x$ & Ramadi & $y=139.107-1.16872 x$ \\
Erbil & $y=380.181-1.22 x$ & Baghdad & $y=158.818-1.9815 x$ \\
Sulaymaniyah & $y=63.8208-2.01 x$ & Hilla & $y=92.1434+1.002 x$ \\
Kirkuk & $y=34.3646-1.96 x$ & Nukheb & $y=76.9995-0.160256 x$ \\
Tel-Afer & $y=30.0651-1.602 x$ & Baiji & $y=219.69-1.01592 x$ \\
Sinjar & $y=34.9575-2.102 x$ & Samawa & $y=93.3741-4.19 x$ \\
Dukan & $y=832.78-4.60 x$ & Hadithah & $y=156.19-1.58592 x$ \\
Darbandikhan & $y=67.2920-5.01 x$ & Rutba & $y=135.801-1.02945 x$ \\
\hline$y^{*}:$ Rainfall, mm, $x^{\prime}: y e a r$ & & &
\end{tabular}

Rainfall data series of all stations considered in the study were tested for their homogeneity using the three methods discussed earlier. Results of Pettitt test demonstrated that all stations' data are of homogenous nature. The SNHT proved that all stations' data involved in the study are homogenous except for Ramadi station. Whereas the Buishand test showed that, all data are homogenous except for Ramadi, Haditha and Darbandikhan stations. The differences between the three tests are due to the sensitivity of each test to refraction point in the investigated rainfall data series (Costa and Soares, 2009)[27]. As the rainfall data of all stations considered in this work have been passed in one or more tests, they all are considered as successful with this test.

The randomness test results showed that the data of all stations considered in the study are random except for Haditha and Samawah stations.

\section{Meteorological Drought Analysis}

In the current study, the SPI values were estimated for 12-months (SPI-12) for each of the considered meteorological stations individually for the years 1970-2010. Each period starts from January and ends with December. (Mckee et al. 1993; Edossa et al. 2010; Tosic et al. 2010)[9,16,37]. Figure (5) demonstrates the values of SPI-12 for stations of Dukan, Mosul, Baghdad, and Basra as examples. It could be noticed that the highest values of drought for all stations were recorded in the period 2007-2010, where SPI values declined to (-2.5) in some stations such as in Basra station which refer to an extreme drought (see Table (3)). It is worthy to mention that the highest estimated 
value of SPI-12 within the study period were in Khanqin, in 1970 with a value of $(-3.3)$. The figure shows that the severest periods of drought were within the last two decades (1997-2001) and (2007-2010) and for all stations considered in the study.

North-eastern region of Iraq is characterized by drought averages higher than the other affected areas due to high rainfall rates in the area. The largest accumulated rainfall deficit was in Darbandikhan station, with a deficit of 1769.7 $\mathrm{mm}$ and drought duration of 8 years, followed by Dukan station, with a deficit of $958.5 \mathrm{~mm}$, then Sulaymaniyah station with a deficit of $869.6 \mathrm{~mm}$. The severest drought intensity was in Dukan station with $239.6 \mathrm{~mm} /$ year. The study showed that most draught events within study period were ranging between mild drought and mild wet classes according to the classification of SPI. Average percentage of dry years in the study area was $50.1 \%$, which reveal that half of the years within the study period were experiencing droughts.
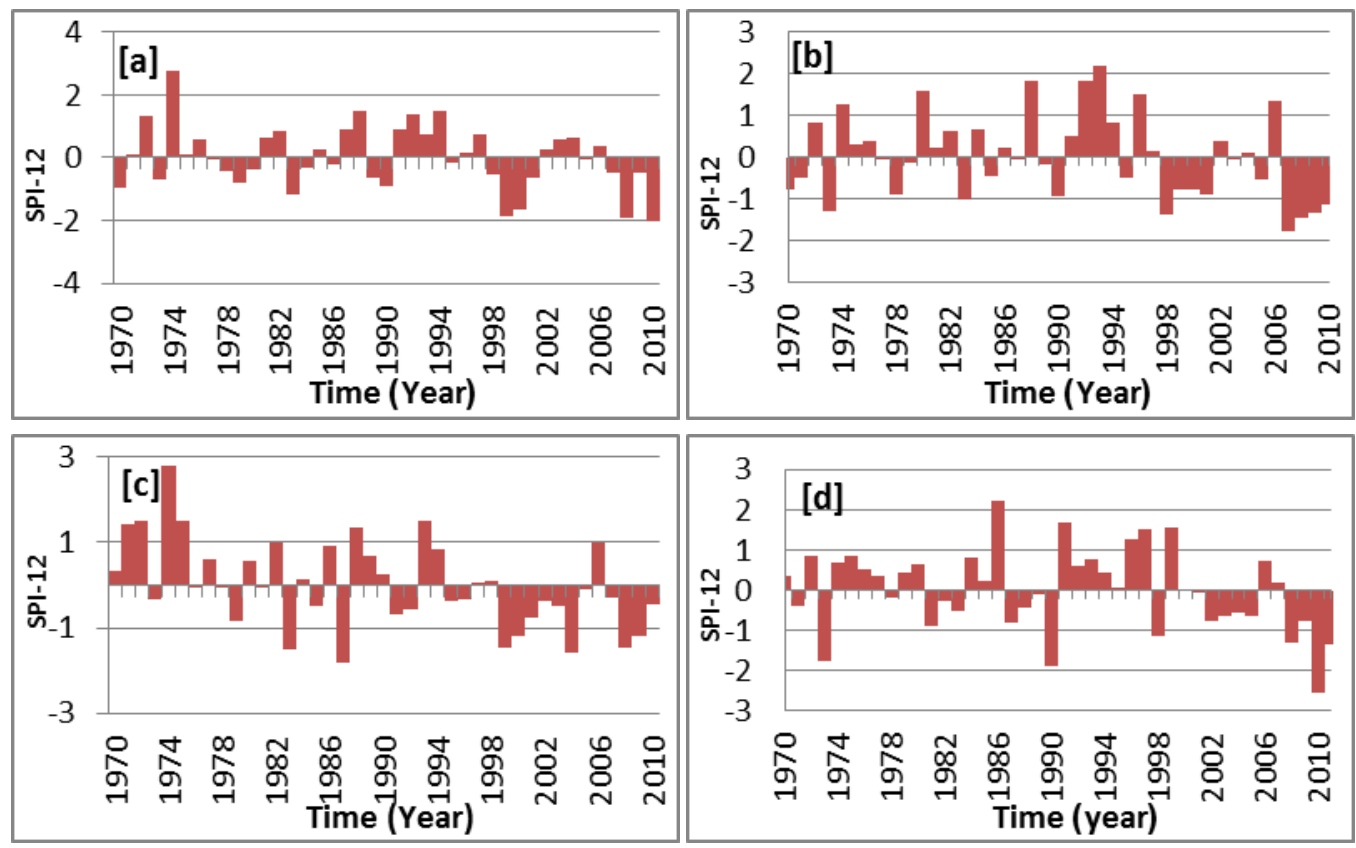

Fig. 5. SPI-12 values for a) Dukan, b) Mosul, c) Baghdad and d) Basra stations

Studying and analysing drought events will provide information that help in managing sustainable water resources in the region. Characteristics of meteorological drought were analysed, and a relationship was suggested between drought magnitude $M$ and drought duration $L$ for each of stations covered in the study which shown in Figure 6 and Table (5). Figure (6) shows the relation between accumulated deficit and drought duration for stations of Dukan, Mosul, Baghdad and Basra as examples. The figures reveal that the accumulated deficit value can be estimated for a certain drought duration.
Moreover, accumulated deficit increases with the increase of drought duration. This applies to all stations covered in the study with one difference that is the curve's slope from a station to another, as shown in Table (5). This relation indicates the need of water used for different purposes in critical periods and helps in managing water resources in a certain area to substitute the deficit between the available water and the demand in areas affected by drought owing to external sources by alternative water resources or through water stored during wet periods. 
Table 5. Relationship between the accumulated deficit $(M)$ and Drought duration (L) for the selected stations using SPI-12

\begin{tabular}{llllll}
\hline Station & \multicolumn{1}{c}{ Equation } & \multicolumn{1}{c}{$\mathrm{R}^{2}$} & Station & \multicolumn{1}{c}{ Equation } & $\mathrm{R}^{2}$ \\
\hline Hadithah & $\mathrm{M}=8.7091 \mathrm{~L}-4.0326$ & 0.8058 & Hilla & $\mathrm{M}=6.5534 \mathrm{~L}-3.6142$ & 0.6587 \\
Nukheb & $\mathrm{M}=5.7344 \mathrm{~L}-3.3545$ & 0.7995 & Samawa & $\mathrm{M}=4.2308 \mathrm{~L}+1.8571$ & 0.6352 \\
Duhok & $\mathrm{M}=34.492 \mathrm{~L}-25.179$ & 0.7723 & Rutba & $\mathrm{M}=4.8568 \mathrm{~L}+1.8858$ & 0.6216 \\
Baghdad & $\mathrm{M}=9.1035 \mathrm{~L}-7.1324$ & 0.7549 & Erbil & $\mathrm{M}=15.164 \mathrm{~L}-4.2128$ & 0.6044 \\
Sulaymaniyah & $\mathrm{M}=41.463 \mathrm{~L}-28.409$ & 0.7295 & Kirkuk & $\mathrm{M}=19.616 \mathrm{~L}-13.678$ & 0.6036 \\
Hai & $\mathrm{M}=8.942 \mathrm{~L}-4.1466$ & 0.7128 & Basra & $\mathrm{M}=7.9257 \mathrm{~L}-3.8327$ & 0.5953 \\
Ramadi & $\mathrm{M}=6.5044 \mathrm{~L}-3.7938$ & 0.7117 & Khanqin & $\mathrm{M}=16.307 \mathrm{~L}-10.447$ & 0.5831 \\
Nasiriya & $\mathrm{M}=9.1074 \mathrm{~L}-4.5389$ & 0.6916 & Sinjar & $\mathrm{M}=13.178 \mathrm{~L}+4.506$ & 0.5647 \\
Darbandikhan & $\mathrm{M}=40.783 \mathrm{~L}-28.104$ & 0.6845 & Dukan & $\mathrm{M}=37.432 \mathrm{~L}-28.057$ & 0.5381 \\
Qaim & $\mathrm{M}=7.7138 \mathrm{~L}-5.2672$ & 0.6722 & Baiji & $\mathrm{M}=6.584 \mathrm{~L}+4.5334$ & 0.5197 \\
Tel-Afer & $\mathrm{M}=17.699 \mathrm{~L}-11.673$ & 0.6706 & Mosul & $\mathrm{M}=11.688 \mathrm{~L}+4.1403$ & 0.4889 \\
\hline & & & & &
\end{tabular}
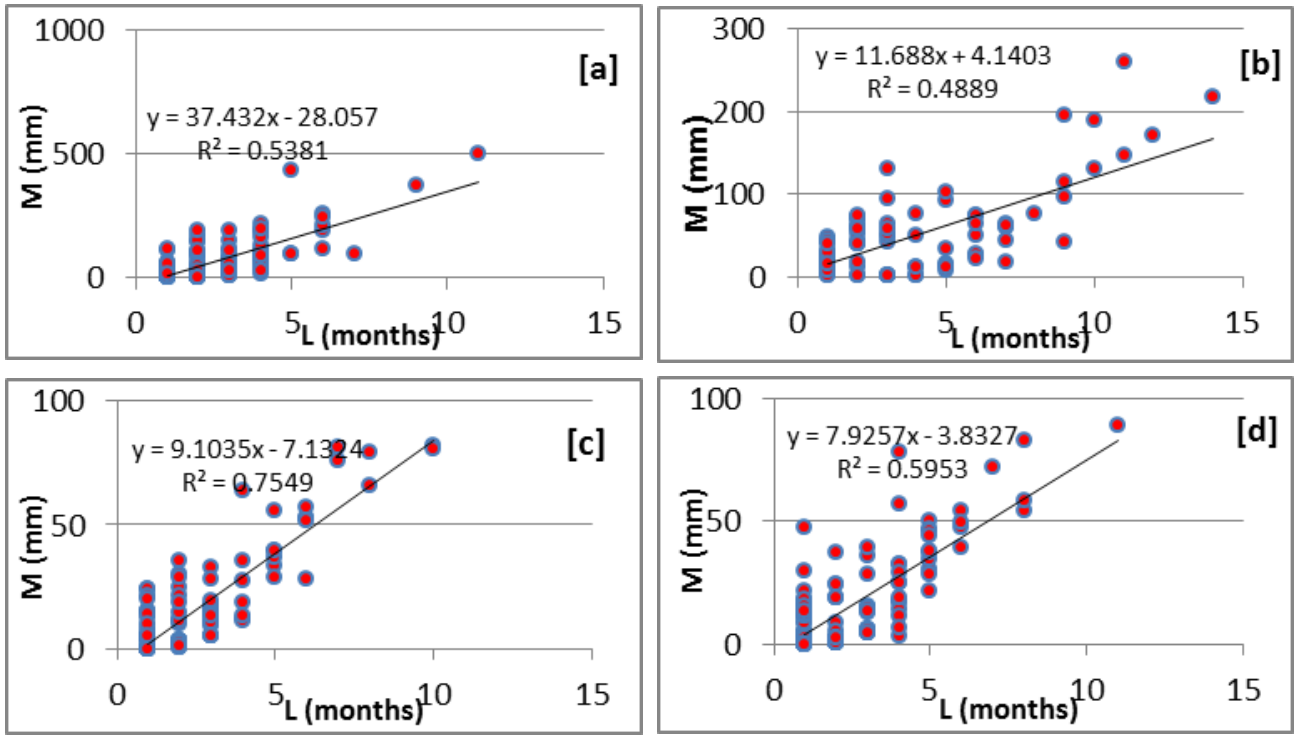

Fig. 6. The relationship between accumulated deficit $(M)$ and drought duration ( $L$ ) for a) Dukan, b) Mosul, c) Baghdad, and d) Basra stations using SPI-12

\section{Conclusions}

1- The statistical tests for the collected rainfall data showed that all rainfall data covered by the study, are consistent. Moreover, rainfall time series are of declining trend except for Hillah station and they were random in all selected stations except for Haditha and Samawah stations.

2- Considering homogeneity, Pettitt's test demonstrated that all stations' data are homogenous, while SNHT showed that the data selected in the study are homogenous except for Al-Ramadi station. However,
Buishand's test proved that the data are homogenous except for Al-Ramadi, Haditha and Darbandikhan stations.

3- Severest periods of drought in Iraq have taken place at the end of the last century and the end of the first decade of this century (1997-2001) and (2007-2010), respectively, in which the extreme drought class was dominant in most of the areas of Iraq.

4- The north-eastern region of Iraq is characterized by drought rates higher than the other affected areas due to high rainfall 
rates in the area. The highest accumulated rainfall deficit is recorded in Darbandikhan station, with deficit depth of $1769.7 \mathrm{~mm}$ and drought duration of 8 years, followed by Dukan station, with depth of $958.5 \mathrm{~mm}$, then Sulaymaniyah station with deficit of 869.6 $\mathrm{mm}$. In addition, the highest drought intensity was in Dukan station with 239.6 $\mathrm{mm} /$ year.

5- The calculated SPI-12 for the considered stations mostly ranged between mild dry and mild wet according to SPI classification, and the percent of the dry years reached to $50.1 \%$ which means that half of the study period years were experiencing drought.

\section{References}

1. Ogallo LJ. Interannual variability of the east african monsoon wind systems and their impact on east african climate. WMO/TD 1994;619:99-104.

2. Kossida M, Koutiva I, Makropoulos C, Monokrousou K, Mimikou M, FonsEsteve J, Iglesias A. Water scarcity and drought: towards a European water scarcity and drought network (WSDN). European Environmental Agency 2009;107.

3. Edwards DC, McKee AT. Characteristics of $20^{\text {th }}$ century drought in the united states at multiple time scale. Climatology Report. Fort Collins, Colorado: Colorado State University; 1997.

4. Norouzi A, Nohegar A, Ghorbani A. Comparison of the suitability of standardized precipitation index (SPI) and aggregated drought index (ADI) in minab watershed (hormozgan province/south of Iran). African Journal of Agricultural Research 2012;7(44): 5905-5911.

5. Loucks DP, Van Bee E. Water resources systems planning and management: an introduction to methods, models and applications, drought management. UNESCO Publishing 2005.

6. Wilhite DA, Glantz $\mathrm{MH}$. Understanding the drought phenomenon: the role of definitions. Water International 1985;10: 111-120.

7. Svoboda MD. The drought monitor. Bull. Am. Meteorol. Soc. 2002;83: 1181-1190.
8. Palmer WC. Meteorological drought (vol.30). Washington, DC: US Department of Commerce, Weather Bureau, 1965.

9. McKee TB. Doesken NJ, Kleist J. The relationship of drought frequency and duration to time scales. In: Proceedings of the $8^{\text {th }}$ Conference on Applied Climatology 1993; Boston, MA: American Meteorological Society 17(22): p. $179-183$.

10. Byun HR, Wilhite DA. Daily quantification of drought severity and duration. Journal of Climate 1999;12(9):2747-2756.

11. Tsakiris G, Pangalou D, Vangelis $H$. Regional drought assessment based on the reconnaissance drought index (RDI). Water Resources Management 2007;21: 821-833.

12. Vicente-Serrano $S M$, Beguería $S$, López-Moreno JI. A multiscalar drought index sensitive to global warming: the standardized precipitation evapotranspiration index. Journal of Climate 2010;23(7):1696-1718.

13. Nam WH, Choi JY, Yoo SH, Jang MW. A decision support system for agricultural drought management using risk assessment. Paddy and Water Environment 2012;10:197-207.

14. Wu JJ, Zhou L, Liu M, Zhang J, Leng S, Diao CY. Establishing and assessing the integrated surface drought index (ISDI) for agricultural drought monitoring in mid-eastern China. International Journal of Applied Earth Observation and Geoinformation 2013;23:397-410.

15. Hao ZC, AghaKouchak A. Multivariate standardized drought index: A parametric multi-index model. Advances in Water Resources-Journal 2013;57: 12-18.

16. Edossa DC, Babel MS, Gupta AD. Drought analysis in the awash river basin, Ethiopia. Water Resources Management 2010;24:1441-1460.

17. Varshney RS, Gupta SC, Gupta RL. Theory and design of irrigation structures. Channels and Tubewells, 4th ed., India: Roorkee Press; 1979.

18. Adeloye AJ, Montaseri M. Preliminary streamflow data analyses prior to water resources planning study/analyses. 
Hydrological Sciences Journal 2002;47(5):679-692.

19. Gocic M, Trajkovic S. Analysis of precipitation and drought data in serbia over the period 1980-2010. Journal of Hydrology 2013;494:32-42.

20. Karpouzos DK, Kavalieratou S, Babajimopoulos C. Trend analysis of precipitation data in pieria region (Greece). European Water 2010;30:3140.

21. Ngongondo C, Xu C, Gottschalk L, Alemaw B. Evaluation of spatial and temporal characteristics of rainfall in Malawi: a case of data scare region. Theoretical and Applied Climatology 2011;106:79-93.

22. Kang HM, Yusof F. Homogeneity tests on daily rainfall series in peninsular Malaysia. International Journal of Contemporary Mathematical Sciences 2012;7(1):9- 22.

23. Piticar A, Ristoiu D. Analysis of air temperature evolution in northeastern romania and evidence of warming trend. Carpathian Journal of Earth and Environmental Sciences 2012;7(4):97106.

24. Alexandersson $\mathrm{H}$. A homogeneity test applied to precipitation data. International Journal of Climatology 1986;6:661-675.

25. Şahin S, Ciğizoğlu HK. Homogeneity analysis of turkish meteorological data set. Hydrological Processes 2010;24(8):981-992.

26. Buishand TA. Some methods for testing the homogeneity of rainfall records. Journal of Hydrology 1982;58:11-27.

27. Costa AC, Soares A. Homogenization of climate data: review and new perspectives using geostatistics. Mathematical Geosciences 2009;41: 291-305.

28. Pettitt AN. A non-parametric approach to the change-point problem. Journal of Applied Statistics 1979;28:126-135.
29. McMahon TA, Mein RG. River and reservoir yield. Littleton, Colorado, USA: Water Resources Publications; 1986.

30. Vezzoli R, Pecora S, Zenoni E, Tonelli F. Data analysis to detect inhomogeneity, change points, trends in observations: an application to Po river discharge extremes. Research Papers Issue RP0138 July 2012 Impact on Soil and Coasts Division (ISC), 2012.

31. Cacciamani C, Morgillo A, Marchesi S, Pavan V. Monitoring and forecasting drought on a regional scale: emiliaromagna region. Water Science and Technology Library 2007;62(1):29-48.

32. Komuscu, AU. Using the SPI to analyse spatial and temporal patterns of drought in Turkey. Drought Network News (19942001) 1999;49.

33. Bordi I, Sutera A. Drought monitoring and forecasting at large scale. In Methods and Tools for Drought Analysis and Management 2007; Springer Netherlands.

34. Yevjevich V. Objective approach to definition and investigations of continental hydrologic droughts. Hydrology Paper No. 23, Colorado State University, Fort Collins, Colorado, USA, 1967.

35. Cancelliere A, Bonaccorso B, Cavallaro L, Rossi G. Regional drought identification module REDIM. M.Sc. Thesis. Italy: University of Catania; 2005.

36. Sirdaş S, Şen Z. Spatio-temporal drought analysis in the trakya region, Turkey. Hydrological Sciences Journal 2003;48(5):809-820.

37. Tosic I, Krzic A, Djurdjevic V, Unkasevic $M$, Rajkovic B.vDrought analysis in serbia using the standardized precipitation index. EMS Annual Meeting Abstracts 2010;7:392. 